\title{
Malay Language Learning Strategy among Chinese Excellent Students in Chinese National Type School
}

\author{
Zamri Mahamod1, Mohamad Yazid Mohamad1, Abdul Rasid Jamian² \\ ${ }^{1}$ Faculty of Education, Universiti Kebangsaan Malaysia, Bangi, Malaysia \\ ${ }^{2}$ Faculty of Language and Communication, Universiti Pendidikan Sultan Idris, Tanjung Malim, Malaysia \\ Email: d-zam@ukm.edu.my
}

How to cite this paper: Mahamod, Z., Mohamad, M. Y., \& Jamian, A. R. (2021). Malay Language Learning Strategy among Chinese Excellent Students in Chinese $\mathrm{Na}$ tional Type School. Creative Education, 12, 1338-1348.

https://doi.org/10.4236/ce.2021.126102

Received: May 25, 2021

Accepted: June 22, 2021

Published: June 25, 2021

Copyright (c) 2021 by author(s) and Scientific Research Publishing Inc. This work is licensed under the Creative Commons Attribution-NonCommercial International License (CC BY-NC 4.0). http://creativecommons.org/licenses/by-nc/4.0/

\begin{abstract}
The purpose of this study is to identify Malay language learning strategies among Chinese excellent students in a Chinese National Type School, Malaysia. This study will identify the different Malay language learning strategies as a second language by gender, learning year, family socio-economy background and the correlation between the Malay language learning strategies and the academic achievement among Chinese excellent students. The sample consists of 291 students categorized as high achievers. In achieving the purpose of the study, a questionnaire is used to collect the data. Data were analysis using Statistical Packages for the Social Science (SPSS) version 23.0 to analysis descriptive. Result indicated that the excellent Chinese students are influenced by all Malay language learning strategies. It showed that the most influential strategy is writing followed by reading, speaking and listening in Malay language learning. In conclusion, although Malay language learning strategy did not influence the students' academic achievement, by having suitable strategy can help the Chinese students to learn affectively Malay language as a second language.
\end{abstract}

\section{Keywords}

Malay Language, Language Learning Strategies, Excellent Students, Second Language

\section{Introduction}

Language learning strategy is a special step or action taken by students to facilitate the acquisition, storage, reminder, and use of information in order to make learning easier, faster, more enjoyable, more independent, more effective, and 
easier to move to a new atmosphere. This involves a mental and communicative procedure to learn and use the language in order to improve the achievement and mastery of the target language or second language.

Some studies on the relationship between language learning strategy and language proficiency indicate that, learning strategies have a positive impact on language performance. Excellent students use various strategies and coordinate the use of strategies more effectively than weak language learners (Mahamod \& Ngumbang, 2018; Oxford, 1990). This is because language learning strategies have the potential to be a powerful learning tool (O'Malley et al., 1985). Therefore, serious attention should be given to teachers, students, and language learners on language learning strategies for the success of language learning.

Lots of studies on language learning strategies are conducted in English as a second language. However, a fewer studies examined the Malay language as a second language or third language by non-native speakers like Chinese ethnic students. On this factor, the researchers wanted to investigate how the Chinese excellent students do well to learn Malay Language as a second language or third language. What language learning strategies they use when learning the Malay Language? Through this study, we can find out the type of strategies by four language skills that excellent Chinese students often use.

In this context, a study to identify the use of language learning strategies for Chinese students in learning Malay was conducted to obtain accurate information on the use of language learning strategies by different groups of students from different levels and cultures. This is to prevent the occurrence of ethnocentric prejudices in defining and describing good language learning strategies (Embi, 2000) that students use. The findings obtained from the study can be used as a catalyst and an inspirational idea for teachers to be introduced and applied in their teaching. According to Jaafar (2020), such studies have been able to change the language teaching and learning method from less effective to more effective and confident. Teachers will not be able to use the strategies in their teaching until they are full with confidence with the accuracy and correctness of the outcomes of study on language learning strategy (Ali \& Othman, 2018).

\subsection{Problem Statement}

Exciting and diverse language learning strategies can help students learn more easily, especially for those who are not native speakers of a language. Mahamod (2015) argued that the diversity of learning strategies used by various teachers can stimulate an individual's interest in learning languages, supported by Lessard-Clouston (1997) in their study of the acquisition of the second language of an individual. Therefore, a teacher should practice more appropriate and practical learning and teaching strategies to the students in line with their level of intelligence.

Research on learning strategies has proved to be crucial in the process of language acquisition. Research on the interest of learning strategies practiced by western language students has long been practiced. According to Mahamod et al. 
(2014) and Mahamod et al. (2021), studies on Malay language learning and teaching strategy focusing more on learning foreign languages or second language in Malaysia are still underdeveloped. Consequently, this has sparked the interest and awareness of researchers and language educators on the importance of effective learning strategies that need to be applied by an educator in the classroom to be consistent with their intelligence levels (Jaafar, 2020; Ghani, 2015; Song, 2020).

The study conducted by Peng (2016) stated that Chinese students are weak in Malay language for all language skills. The study by Siew and Mahamod (2021) found that Chinese students in Chinese national-type schools had problems in Malay language learning process. The problem is due to internal factors related to self and external factors such as environmental influences, less effective teaching methods and others. But the question is, does language learning strategy also affect the achievement of Malay language among Chinese students? Therefore, a study on the excellent pupil's learning strategy in the Chinese national-type school need to be done to answer the questions raised. This study also conducted to identify the students' excellence in the Malay language based on language learning strategies practiced in learning Malay language.

In this case, excellent students are models to other students. This includes learning, time management and motivation behind their success. When students with low academic achievement learn about the strategies and effective learning practices practiced, this can help them to be excellent students as well. Hence, this study aims to provide a guide to students for excellent results especially in Malay language subjects. In addition, it can also eradicate confusion about the appropriate learning pattern practiced so that weak students can come up with excellent results. Thus, these conditions enable them to improve their performance in learning.

\subsection{Purposes and Objectives of Study}

This study is aimed at reviewing Malay language learning strategies among Chinese excellent students. In particular, the objective of this study was to:

1) Identify the type of and frequency Malay language learning strategies used by the excellent Chinese students in listening skills.

2) Identify the type of and frequency Malay language learning strategies used by the excellent Chinese students in speaking skills.

3) Identify the type of and frequency Malay language learning strategies used by the excellent Chinese students in reading skills.

4) Identify the type of and frequency Malay language learning strategies used by the excellent Chinese students in writing skills.

\section{Significant This Study}

This study is conducted to identify the Malay language learning strategies used by Chinese excellent students in Chinese national-type schools in writing skills. This study is conducted to provide feedback on the actual situation of students' 
learning and can be used by various parties to improve the quality of Malay Language as a second language at Chinese national-type schools.

The results of this study can provide an overview of the Malay language learning strategies used by non-Malay students in language learning, especially in writing skills in the classroom or outside of the classroom. Malay language teachers will get a direct exposure to language learning strategies that are practical for language learning in reading and writing skills.

This study also provides guidance to Malay language teachers to select and use appropriate language learning strategies and to provide basic teachers to design their own learning strategies and language learning that is more appropriate to improve the students' ability to build the essay well. This study also helps the Malay language teachers to plan and define the approaches, techniques and methods of teaching that are more appropriate in the classroom especially for students learn Malay language as a second language or foreign language.

\section{Methodology}

\subsection{Design of Study}

In order to implement this study, researchers have been using cases descriptive research. In this study, the information of the students involved is collected through questionnaires. According to Piaw (2006), questionnaires are frequently used instruments in descriptive research. The use of survey method using questionnaire facilitates researchers to get cooperation from respondents (Creswell, 2014). Researchers used questionnaires as they were easy to administer, data were easily quoted and analysis.

\subsection{Quantitative of Study}

The quantitative study was conducted using questionnaires as the data needed involving a certain interval of time. In this study, the researcher observed on the students' Malay language learning strategy. The study focuses on quantitative data collection. Therefore, the questionnaire was used as an instrument in this study to collect information and data from the respondents.

\subsection{Population and Sampling}

Through this study, the population consists of Chinese national type school second level students i.e. year 4, year 5 and year 6. A total of 291 from 573 student year 4, 5 and 6 were selected as a sampling. The sample was selected by purpose sampling. This study was conducted in one Chinese national type school in Hulu Langat District, Selangor, Malaysia. The school were chosen because many Chinese students who have a good Malay language.

\subsection{Instrument of Study}

In this study, the researcher used the questionnaire instrument from Mahamod (2004) and being modified according to the title and the elements of the study. 
The first part, which is section A, is related to the background information of the respondents. In the second part, the survey form used the option of five Likert scale, ie. Strong Disagree (SD), Disagree (D), Undecided (UD), Agree (A), and Strongly Agree (SA).

\subsection{Data Analysis}

The reviewers analyzed quantitative data using the SPSS version 23.0. This descriptive analysis is used for two main purposes. The first one is to describe the demographics of sample studies such as percentage and frequency. Second, statistical analysis is made based on the interpretation of min scores from Konting (2005), such 1.00 - 2.33 (low), 2.34 - 3.66 (medium) and 3.67 - 5.00 (high).

\section{Findings}

\subsection{Respondent Demographics}

The study involved 291 Chinese students with various backgrounds such as gender. The respondents' demographic data is detailed in Table 1. Table 1 shows that based on gender, from a total of 291 respondents, there are 119 male students (40.9\%) and 172 students female (59.1\%). This shows that the composition by gender is not equal or there is a difference. Respondents in this study are students selected from Level 2, namely students of year 4, 5, and 6 . Out of the total 291 study sample, a total of $97(33.3 \%)$ respondents are student year 4, 97 (33.3\%) student year 5 and 97 (33.3\%) student year 6.

\subsection{Listening Learning Strategy}

The findings of this study address the objective 1: Identify the Malay language learning strategies used by the excellent Chinese national-type school students by listening skills. Table 2 shows descriptive analysis involving total frequency, percentage, mean and standard deviation and the level achieved by the mean score of each item on oral learning strategy. Out of 10 items, there are 3 items at highest level and 7 items at medium level. The findings shows that mean value for listening strategy is mean 3.22, which is at medium level. A statement with a mean interpretation level by item 10 (Listen to people who speak Malay and try to understand what they say) with a high mean score of 3.86, followed by item 1 (Listen carefully to Malay teachers in class) with a score of 3.72 and item 3 (Listen to Malay friends while they talk) with a mean score of 3.71. While there are three items at the high level, on average oral learning strategy is at a medium level. Meanwhile, the item that obtained the lowest mean was item 6 (Ask Malay friend to repeat the new word that just being heard) with a mean of 3.35, followed by item 4 (Give full attention to teachers during teaching in class) with a mean of 3.43. The summary of these findings is:

1) Chinese ethnic students have only moderate level of listening skills in Malay language learning only.

2) Chinese students understand and acknowledge that by listening carefully, they can understand the Malay language well. 
Table 1. Respondent profile based on gender.

\begin{tabular}{|c|c|c|c|}
\hline \multicolumn{2}{|c|}{ Profile } & \multirow{2}{*}{$\begin{array}{c}\text { Frequency }(\mathrm{N}=291) \\
119\end{array}$} & \multirow{2}{*}{$\begin{array}{c}\text { Percentage (\%) } \\
40.9\end{array}$} \\
\hline & Male & & \\
\hline Geriut & Female & 172 & 59.1 \\
\hline \multirow{3}{*}{ Year } & 4 & 97 & 33.3 \\
\hline & 5 & 97 & 33.3 \\
\hline & 6 & 97 & 33.3 \\
\hline
\end{tabular}

Table 2. Listening skill of Malay language learning strategy among Chinese excellent students.

\begin{tabular}{|c|c|c|c|c|c|c|c|c|c|}
\hline No & Item & SD & $\mathrm{D}$ & UD & A & SA & Mean & SD & Level \\
\hline 1 & Listen carefully to teachers in class & $12(4.1 \%)$ & $35(12 \%)$ & $55(43.2 \%)$ & $109(34.2 \%)$ & $80(3.5 \%)$ & 3.72 & 1.115 & High \\
\hline 2 & Pay attention to the specific language needs & $11(3.8 \%)$ & $46(15.8 \%)$ & $64(22.0 \%)$ & $102(35.1 \%)$ & $68(23.4 \%)$ & 3.58 & 1.121 & Medium \\
\hline 3 & Listen to Malay friends while they talk & $8(2.7 \%)$ & $34(11.7 \%)$ & $63(21.6 \%)$ & $114(39.2 \%)$ & $72(24.7 \%)$ & 3.71 & 1.049 & High \\
\hline 4 & $\begin{array}{l}\text { Give full attention to teachers during teaching } \\
\text { in class }\end{array}$ & $5(1.7 \%)$ & $53(18.2 \%)$ & $85(29.2 \%)$ & $108(37.1 \%)$ & $40(13.7 \%)$ & 3.43 & 0.995 & Medium \\
\hline 5 & Listen to Malay radio program & $4(1.4 \%)$ & $41(14.1 \%)$ & $96(33.0 \%)$ & $107(36.8 \%)$ & $43(14.8 \%)$ & 3.49 & 0.955 & Medium \\
\hline 6 & $\begin{array}{l}\text { Ask Malay friend to repeat the new word that } \\
\text { just being heard }\end{array}$ & $10(3.4 \%)$ & $50(17.2 \%)$ & $95(32.6 \%)$ & $100(34.4 \%)$ & $36(12.4 \%)$ & 3.35 & 1.014 & Medium \\
\hline 7 & $\begin{array}{l}\text { Try to understand what is being heard without } \\
\text { looking for the meaning in a dictionary }\end{array}$ & $8(2.7 \%)$ & $47(16.2 \%)$ & $73(25.1 \%)$ & $112(38.5 \%)$ & $51(17.5 \%)$ & 3.52 & 1.045 & Medium \\
\hline 8 & Watch a Malay television program & $5(1.7 \%)$ & $35(12.0 \%)$ & $92(31.6 \%)$ & $121(41.6 \%)$ & $38(13.1 \%)$ & 3.52 & 0.926 & Medium \\
\hline 9 & $\begin{array}{l}\text { Ask for explanation if I did not understand the } \\
\text { first time I heard it }\end{array}$ & $3(1.0 \%)$ & $48(16.5 \%)$ & $77(26.5 \%)$ & $113(38.8 \%)$ & $50(17.2 \%)$ & 3.55 & 0.993 & Medium \\
\hline 10 & $\begin{array}{l}\text { Listen to people who speak Malay and try to } \\
\text { understand what they say }\end{array}$ & $3(1.0 \%)$ & $17(5.8 \%)$ & $66(22.7 \%)$ & $137(47.1 \%)$ & $68(23.4 \%)$ & 3.86 & 0.877 & High \\
\hline & Overall & & & & & & 3.22 & 1.009 & Medium \\
\hline
\end{tabular}

\subsection{Speaking Learning Strategy}

The findings of this study address the objective 2: Identify the Malay language learning strategies used by the excellent Chinese national-type school students by speaking skills. Descriptive analysis involving frequency, percentage, standard deviation and min conducted to identify the learning strategy of speaking language of among student. The results of descriptive analysis such as Table 3 for speaking language learning strategy show that average mean score of 3.34, with a medium level. Out of 10 items, only item 10 at the high level and 9 item are at medium level. The highest is on item 10 (Ask for help from a classmate) with a mean score of 3.86. Meanwhile, item 4 (mean 3.17), item 2 (mean 3.23), item 1 (mean 3.25), item 6 (mean 3.26) and item 7 (mean 3.27) categorized as a lowest mean item, but at the medium level. Of these items, item 4 (Practice in spelling words) which mean 3.17 obtained the lowest mean item. The conclusions that can be made are:

1) Students ethnic Chinese have the skills strategy Malay speakers in medium level. 
Table 3. Speaking skill of Malay language learning strategy among Chinese excellent students.

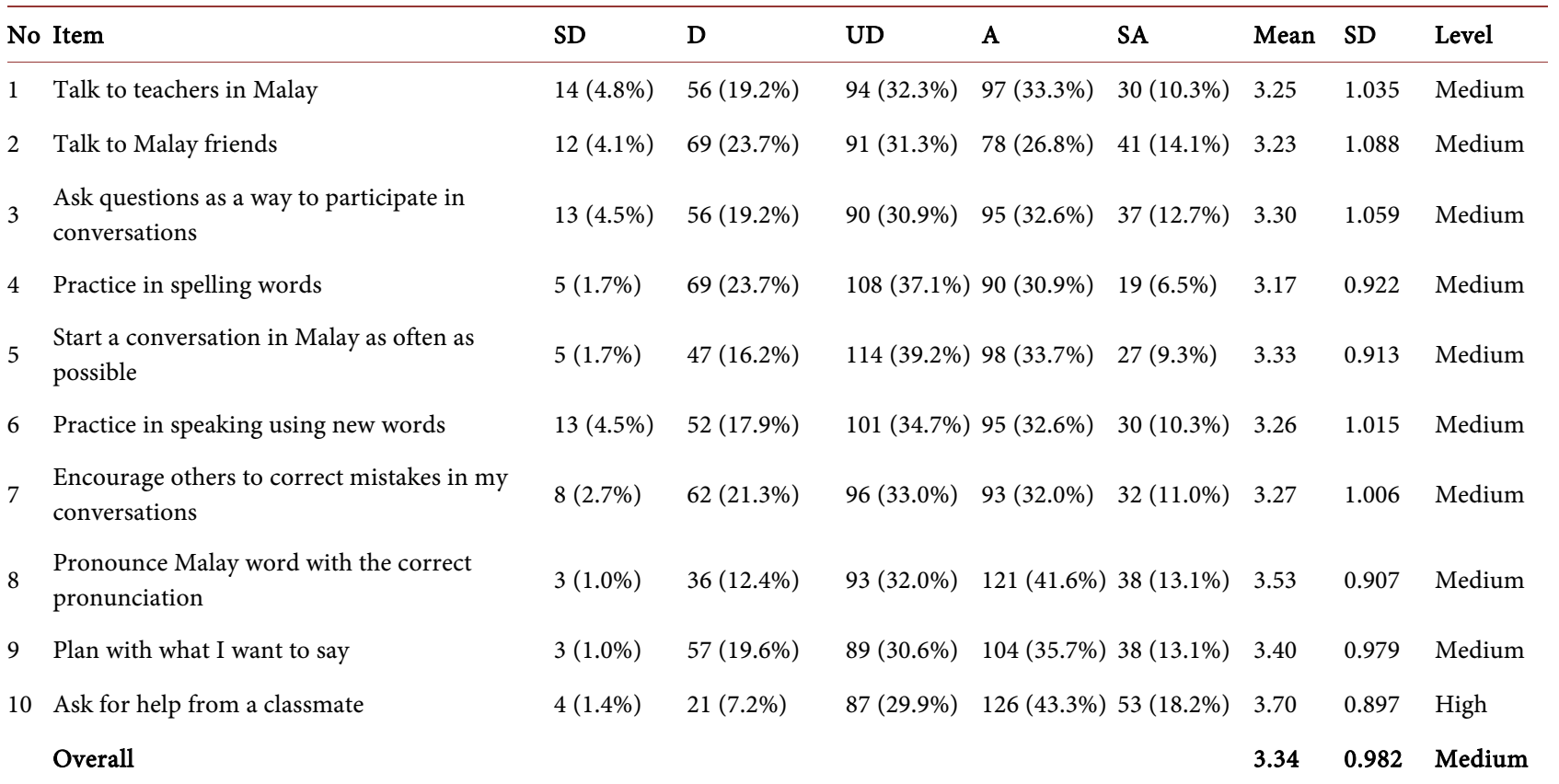

2) Students ethnic Chinese less use of Malay language speaking skills strategy.

3) Students ethnic Chinese more ask classmates to master the Malay language speaking skills strategy.

\subsection{Reading Learning Strategy}

The findings of this study address the objective 2: Identify the Malay language learning strategies used by the excellent Chinese national-type school students by reading skills. Descriptive analysis involves frequency, percentage, standard deviation and mean to identify the reading learning strategy of the students. The results of descriptive analysis show in Table 4 . There are 4 items at highest level and 6 items are at medium level. Average mean score of 3.64, with a medium level.

The statement with the highest mean level is the item 1 (Re-reading the Malay text to improve understanding) with a mean score of 3.98 and followed by item 10 (Guessing the meaning of the Malay text without looking at the dictionary), item 2 (Read the Malay text at first view before reading carefully) with a mean score of 3.85. In addition, item 3 (Reading Malay language subtitles in television shows) is also at a high level with a mean score of 3.77 and item 10 (Guessing the meaning of the Malay text without seeing the dictionary) with a mean score of 3.89. Meanwhile, item 6 (Look for easy-to-understand reading materials) with mean score 0.38 and item 4 (Read Malay books as much as possible) with mean score 3.43 is the item that obtains the lowest mean score but is still categorized as medium level. Inclusion this data show that:

1) Student ethnic Chinese reading skills using a variety of strategies to learn Malay language. 
Table 4. Reading skill of Malay language learning strategy among Chinese excellent students.

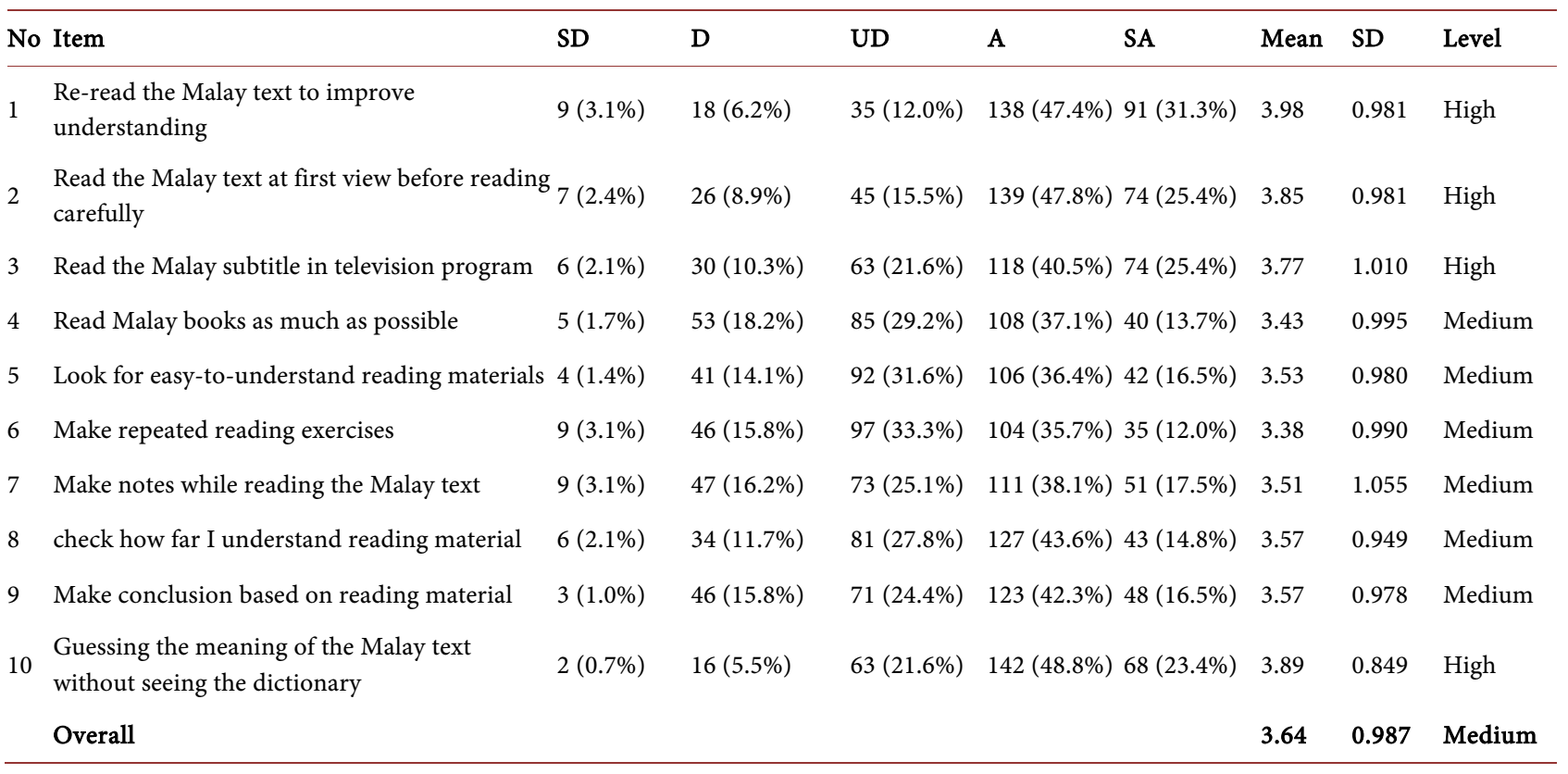

2) Student ethnic Chinese Students read a lot of books/materials in the Malay language to improve Malay language.

3) Student ethnic Chinese refer dictionary to know the meaning of the word Malay language.

\subsection{Writing Learning Strategy}

The findings of this study address the objective 2: Identify the Malay language learning strategies used by the excellent Chinese national-type school students by writing skills. Descriptive analysis involving frequency, percentage, standard deviation and mean conducted to identify the learning strategy of the reading language of the students. The result of descriptive analysis shows in Table 5.

Out of 10 items, there are 5 items at the high level and 5 items are at medium level. Average mean score of 3.72, with a high level. Item 1 (Practice writing new words in Malay) is the item with the highest mean score of 4.13, and followed by item 2 (Using the dictionary to help find the word in the Malay language) with mean score of 3.92, item 10 (Trying to write various types of Malay text) with mean score of 3.88. Two more item at high level is item 3 (Writing the meaning of the word in Malay language) with a mean score of 3.83 and item 8 (Design a way to write an essay by writing an essay frame first) with a mean score of 3.68. Meanwhile item 6 (Show the writing to a Malay friend) is the item with the lowest mean score of 3.51 and the categorized is medium level. The findings show that:

1) Learning strategy of writing skills is a strategy used by many student ethnic Chinese in learning the Malay language.

2) Students ethnic Chinese make training to improve writing in the Malay language learning. 
Table 5. Writing skill of Malay language learning strategy among Chinese excellent students.

\begin{tabular}{|c|c|c|c|c|c|c|c|c|c|}
\hline No & Item & SD & $\mathrm{D}$ & UD & A & SA & Mean & SD & Level \\
\hline 1 & Practice writing new words in Malay & $8(2.7 \%)$ & $10(3.4 \%)$ & $24(8.2 \%)$ & $142(48.8 \%)$ & $107(36.8 \%)$ & 4.13 & 0.905 & High \\
\hline 2 & $\begin{array}{l}\text { Use dictionaries to help search for words in } \\
\text { Malay }\end{array}$ & $9(3.1 \%)$ & $18(6.2 \%)$ & $33(11.3 \%)$ & $158(54.3 \%)$ & $73(25.1 \%)$ & 3.92 & 0.942 & High \\
\hline 3 & $\begin{array}{l}\text { Writing the meaning of the word in Malay } \\
\text { language }\end{array}$ & $5(1.7 \%)$ & $26(8.9 \%)$ & $57(19.6 \%)$ & $129(44.3 \%)$ & $74(25.4 \%)$ & 3.83 & 0.967 & High \\
\hline 4 & $\begin{array}{l}\text { Check out what I wrote before continuing to } \\
\text { write }\end{array}$ & $4(1.4 \%)$ & $48(16.5 \%)$ & $75(25.8 \%)$ & $117(40.2 \%)$ & 47 (16.2\%) & 3.53 & 0.994 & Medium \\
\hline 5 & Write note in Malay & $7(2.4 \%)$ & $37(12.7 \%)$ & $83(28.5 \%)$ & $114(39.2 \%)$ & $50(17.1 \%)$ & 3.56 & 1.003 & Medium \\
\hline 6 & Show the writing to a Malay friend & $10(3.4 \%)$ & $35(12.0 \%)$ & $83(28.5 \%)$ & $123(42.3 \%)$ & $40(13.7 \%)$ & 3.51 & 0.987 & Medium \\
\hline 7 & Check written words to improve content & $11(3.8 \%)$ & $42(14.4 \%)$ & $67(23.0 \%)$ & $116(39.9 \%)$ & $55(18.9 \%)$ & 3.56 & 1.070 & Medium \\
\hline 8 & $\begin{array}{l}\text { Design a way to write an essay by writing an } \\
\text { essay frame first }\end{array}$ & $3(1.0 \%)$ & $29(10.0 \%)$ & $76(26.1 \%)$ & $133(45.7 \%)$ & $50(17.2 \%)$ & 3.68 & 0.908 & High \\
\hline 9 & Write words that are easy to understand. & $5(1.7 \%)$ & $43(14.8 \%)$ & $64(22.0 \%)$ & $117(40.2 \%)$ & $62(21.3 \%)$ & 3.65 & 1.028 & Medium \\
\hline \multirow[t]{2}{*}{10} & Try to write various types of Malay texts & $6(2.1 \%)$ & $13(4.5 \%)$ & $59(20.3 \%)$ & $144(49.5 \%)$ & $69(23.7 \%)$ & 3.88 & 0.891 & High \\
\hline & Overall & & & & & & 3.72 & 0.970 & High \\
\hline
\end{tabular}

3) Student ethnic Chinese using various types of text and materials to improve the writing skills of the Malay language learning.

4) Student ethnic Chinese will find the meaning of words that are difficult to master the Malay language learning with reference dictionary.

\section{Discussion}

From the study, it was found that the Chinese excellent students at the Chinese National-Type School were influenced by all the stimulus of learning expressed. However, writing strategy affects students strongly as the other learning strategies are less likely to influence students' language learning strategy, followed by reading strategy, speaking strategy and listening strategy. The findings parallel with the study by Siew and Mahamod (2021) and Mahamod et al. (2021). The findings of study found that excellent Chinese students use many strategies to reading and writing, but less likely to use strategies when learning to speaking during Malay language learning. The similar findings also found in Peng (2016) study.

Besides, the findings also show that the Malay language learning strategies of the Chinese excellent students while studying Malay language that affect the way they learn Malay as second language. To form a positive attitude in students to learn Malay, teachers need to take responsibility to jointly cultivate positive attitudes and motivations. The findings are consistent with the findings obtained by Peng (2016), and Jaafar (2020) where the teachers need to always give positive reinforcement to students in the process of language learning. 


\section{Conclusion and Implication of Study}

Overall, this study has identified the language learning strategies amongst excellent students. The findings can provide some insights and suggestions that can be used as a guide on language learning strategies that are appropriate for students studying the second language. Therefore, this study is expected to be used as a guide and reference to teachers to address the problems faced by the students during the learning process of Malay as the second language in school. Students' attitudes, knowledge and readiness can be enhanced with the support and cooperation of teachers in the classroom. The implications of this study are:

1) The non-Malay student uses a variety of strategies to learn Malay language through four language skills.

2) The Malay language is easy to learn as second language by non-native speakers.

3) Malay language teachers can use a variety of Malay language learning strategies to teach non-native speakers, especially weak student to learn Malay language as a second language.

\section{Acknowledgements}

Thanks to the Ministry of High Education for providing the Fundamental Research Grant Scheme research code: FRGS/1/2018/SS109/UKM/01/1 till this article is successfully published.

\section{Conflicts of Interest}

The authors declare no conflicts of interest regarding the publication of this paper.

\section{References}

Ali, N. H., \& Othman, Y. (2018). Writing Skill Learning Strategies in Malay Language as a Second Language among Melanau Ethnic Students at Daro District, Malaysia. Journal Malay Language Education, 8, 33-41.

Creswell, J. W. (2014). Research Design: Qualitative, Quantitative and Mixed Methods Approaches. Thousand Oaks, CA: SAGE Publications.

Embi, M. A. (2000). Language Learning Strategies: A Malaysia Context. Bangi: Universiti Kebangsaan Malaysia Press.

Ghani, K. A. A. (2015). Malay Language Learning Strategies among Non-Malay Students. Master Project Paper. Bangi: Faculty of Education, Universiti Kebangsaan Malaysia, Malaysia.

Jaafar, R. (2020). Learning Strategy in Listening and Writing Skills among Chinese and Indian Ethnic Student When Learning of Malay Language. Journal Malay Language Education, 10, 64-76.

Konting, M. M. (2005). Educational Research Methode (5th ed.). Kuala Lumpur: Dewan Bahasa and Pustaka Press.

Lessard-Clouston, R. (1997). Language Learning Strategies: An Overview for L2 Teachers. The Internet TESL Journal, 3, 33-42. 
Mahamod, Z. (2004). Malay Language Learning Strategies among Secondary School Students. Doctor of Philosophy Thesis, Bangi: Faculty of Education, Universiti Kebangsaan Malaysia.

Mahamod, Z., Badusah, J., Nik Yusoff, N. M. R., Embi, M. A., \& Subramaniam, S. (2014). Using and Frequency of Use Malay Language Learning Strategies of among Foreign Students. Journal Malay LanguageEducation, 4, 25-35.

Mahamod, Z. (2015). Learning Strategy: Learning How to Learn Malay Language Inventory. Kuala Lumpur: Dewan Bahasa \& Pustaka Press.

Mahamod, Z., \& Ngumbang, N. (2018). Attitude and Motivation of Melanau Ethnic Students in Learning Malay Language as a Second Language. Journal of Advance Research in Dynamical and Control System, 10, 1488-1494.

Mahamod, Z., Ghani, K. A. A., Mazlan, R., Amin, N., Jamian, A. R., \& Othman, S. (2021). Malay Language Learning Strategies Use among Chinese Students through Attitude and Learning Skills. Turkish Journal of Computer and Mathematics Education, 12, 31-43. https://doi.org/10.17762/turcomat.v12i5.728

O’Malley, J. M., Chamot, A. U., Stewner-Manzanaraes, G., Kupper, L., \& Russo, R. (1985). Learning Strategies Used by Beginning and Intermediate ESL Students. Language Learning, 35, 21-46. https://doi.org/10.1111/j.1467-1770.1985.tb01013.x

Oxford, R. (1990). Language Learning Strategies: What Every Teacher Should Know. Rowley, MA: Newbury House.

Peng, C. F. (2016). Problem Learning in Malay Language among Primary Schools Chinese Student. Journal Malay Language Education, 6, 10-22.

Piaw, C. Y. (2006). Research Basic Statistic: Book 1. Petaling Jaya: McGraw Hill (M) Inc.

Siew, H. S., \& Mahamod, Z. (2021). Frequency Using of Malay Language Writing Skills Strategies among Chinese and Ibanese Excellent Students. Journal of Dunia Pendidikan, 3, 122-133.

Song, M. A. (2020). Malay Language Learning Strategies among High Education Institute Students at Yala District, South Thailand. Thesis Master, Bangi: Faculty of Education, Universiti Kebangsaan Malaysia. 